\title{
AT-CUAAC Synthesis of Mechanically Interlocked Oligonucleotides
}

\author{
Amanda Acevedo-Jake, ${ }^{1, \ddagger}$ Andrew T. Ball, ${ }^{1, \ddagger}$ Marzia Galli, ${ }^{1, \ddagger}$ Mikiembo Kukwikila, ${ }^{1, \ddagger}$ Mathieu Den- \\ is, ${ }^{1}$ Daniel G. Singleton, ${ }^{2}$ Ali Tavassoli ${ }^{1, *}$ and Stephen M. Goldup ${ }^{1, *}$
}

\author{
${ }^{1}$ Chemistry, University of Southampton, Highfield, Southampton, SO17 1BJ, UK. \\ ${ }^{2}$ ATDBio Ltd, School of Chemistry, University of Southampton, Highfield, Southampton, SO17 1BJ, UK.

\section{Supporting Information placeholder}

\begin{abstract}
We present a simple strategy for the synthesis of main chain oligonucleotide rotaxanes with precise control over the position of the macrocycle. The novel DNA-based rotaxanes were analyzed to assess the effect of the mechanical bond on their properties.
\end{abstract}

Mechanically interlocked molecules (MIMs) ${ }^{1}$ based on oligonucleotides ${ }^{2}$ predate even the early synthetic work of Wasserman, Harrison and Schill; 3 catenated DNA, which arises during DNA replication and is managed by topoisomerase enzymes, ${ }^{4}$ was observed as early as 1967 by Vinograd and coworkers, ${ }^{5}$ and threaded structures play an important role in the operation of some DNA polymerase enzymes. ${ }^{6,7}$ To date, artificial oligonucleotide-based MIMs have been produced using DNA self-assembly approaches, ${ }^{8}$ including origami methods. ${ }^{9}$ Although this approach allows the production of complex architectures and stimuli responsive systems, the threaded structures produced are relatively large (ring sizes are typically $>100$ base pairs), and the sequences assembled are not of direct biological relevance. DNA-based MIMs containing non-nucleotide macrocycles have not been reported, presumably as the majority of the methods developed for the synthesis of rotaxanes are not well-suited to the production of functional interlocked DNA; passive template methods ${ }^{1}$ would require significant modification of the sugarphosphate backbone, whereas hydrophobic threading-based approaches are unsuitable due to the hydrophilicity of oligonucleotides.

Tavassoli, Brown and co-workers have developed biocompatible triazole linkages to replace a native phosphodiester bond in an oligonucleotide strand, and have shown this nonnatural modification to be fully biocompatible in bacterial and human cells. ${ }^{10}$ This "click-DNA ligation" approach, overcomes the size limitations of automated DNA synthesis by allowing longer oligonucleotides to be synthesized by $\mathrm{Cu}-$ AAC ligation of $\sim 100$ base fragments functionalized with alkyne or azide handles, for example, in the one-pot synthesis of epigenetically decorated, biocompatible, triazole-linked genes. ${ }^{11}$ Click-DNA ligation also presents an additional opportunity; Leigh's active template ${ }^{12} \mathrm{Cu}$-mediated alkyne/azide cycloaddition (AT-CuAAC) ${ }^{13}$ reaction permits the simultaneous installation of a triazole moiety and the formation of a mechanical bond. ${ }^{14}$

Here we report the synthesis of biologically relevant DNA rotaxanes by combining Goldup's small macrocycle ${ }^{15}$ modifi- cation of the AT-CuAAC reaction with Tavassoli and Brown's click-DNA approach. The mechanical bond significantly alters the supramolecular and biological properties of the oligonucleotide. Our results suggest that the mechanical bond can be used to tailor the behavior of biocompatible DNA.

As the AT-CuAAC reaction had not previously been applied to substituted nucleotides, we began our study by demonstrating the formation of a [2] rotaxane by reaction of propargyl cytosine $\mathbf{1}$ and azido thymine $\mathbf{2}$, models of the chain termini in the click-DNA ligation process, in the presence of macrocycle $3^{16}$ (Scheme 1). Pleasingly, under our standard AT-CuAAC conditions, ${ }^{15}$ rotaxane 4 was produced in excellent isolated yield (83\%). Mass spectrometry confirmed the expected protonated molecular ion of $4(\mathrm{~m} / \mathrm{z}=$ 1470) and the ${ }^{1} \mathrm{H}$ NMR spectrum of the purified product displayed the expected features for such interlocked species; triazole proton $\mathrm{H}_{q}$ appears $1.5 \mathrm{ppm}$ higher in rotaxane 4 than the non-interlocked axle, consistent with the expected $\mathrm{C}$ $\mathrm{H} \cdots \mathrm{N}$ hydrogen bond to the bipyridine unit. ${ }^{15}$ In addition, many macrocycle resonances, including $\mathrm{H}_{A}, \mathrm{H}_{B}, \mathrm{H}_{C}, \mathrm{H}_{F}$, and $\mathrm{H}_{G}$, which appear as single signals in non-interlocked 3 , are split into two signals as the bilateral symmetry of the ring is lifted in the chiral interlocked product. ${ }^{15 a, 17}$

Scheme 1. Synthesis of rotaxane 4 from cytosine-derived alkyne $\mathbf{1}$ and thymine-derived azide $\mathbf{2}$.

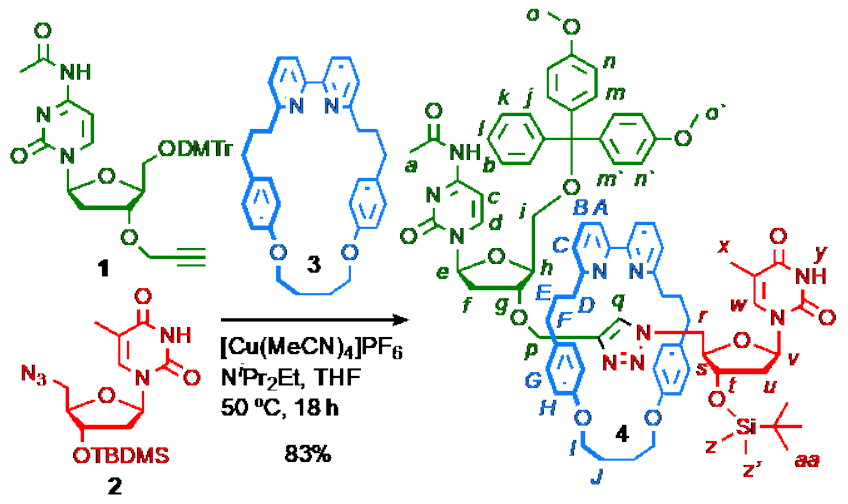

Having demonstrated the synthesis of simple triazolelinked di-nucleotide [2] rotaxane 4 we turned our attention to the challenge of synthesizing a longer interlocked oligonucleotide using the AT-CuAAC approach. For our proof of concept study, we selected the 20 base $\mathrm{T}_{7}$ promoter sequence, widely used in a variety of biological applications. ${ }^{18}$ 
Alkyne 5a and azide $\mathbf{6 a}$ were synthesized using standard solid phase techniques and their AT-CuAAC coupling optimized by systematic modification of the conditions reported for click-DNA ligation (see ESI). Ultimately, reaction of $\mathbf{5 a}^{\mathbf{a}}$ and $\mathbf{6 a}$ in the presence of macrocycle 3 using THF- $\mathrm{H}_{2} \mathrm{O}(\mathbf{1}: \mathbf{1})$ as the solvent, $\mathrm{CuSO}_{4} / \mathrm{Na}$ ascorbate as the source of $\mathrm{Cu}^{\mathrm{I}}$, and $\mathrm{N}^{\mathrm{i}} \mathrm{Pr}_{2} \mathrm{Et}$ as base to accelerate the reaction, gave $\mathrm{T}_{7}$ rotaxane $7 \mathbf{a}$ as the sole product (no non-interlocked axle 1oa was detected by LC-MS analysis) in $83 \%$ isolated yield after HPLC purification. $\mathrm{T}_{7}$-based rotaxane $\mathbf{7} \mathbf{b}$, which differs in the position of the mechanical bond along the DNA backbone, was produced under the same conditions from alkyne $\mathbf{5} \mathbf{b}$ and azide $\mathbf{6 b}$ in $90 \%$ isolated yield. LC-MS analysis confirmed the purity and identity of both interlocked products. Native oligonucleotides $\mathrm{T}_{7}$ forward (8) and non-interlocked triazole axles 10a and 1ob were synthesized separately as control compounds. Strikingly, rotaxanes 7 and axles 10 display significantly different HPLC retention times ( $\sim 8.5$ vs $\sim 7.5 \mathrm{~min}$ respectively), which is surprising given that they differ only by inclusion of macrocycle 3 , a relatively small change compared with the size of a 20 -base oligonucleotide.

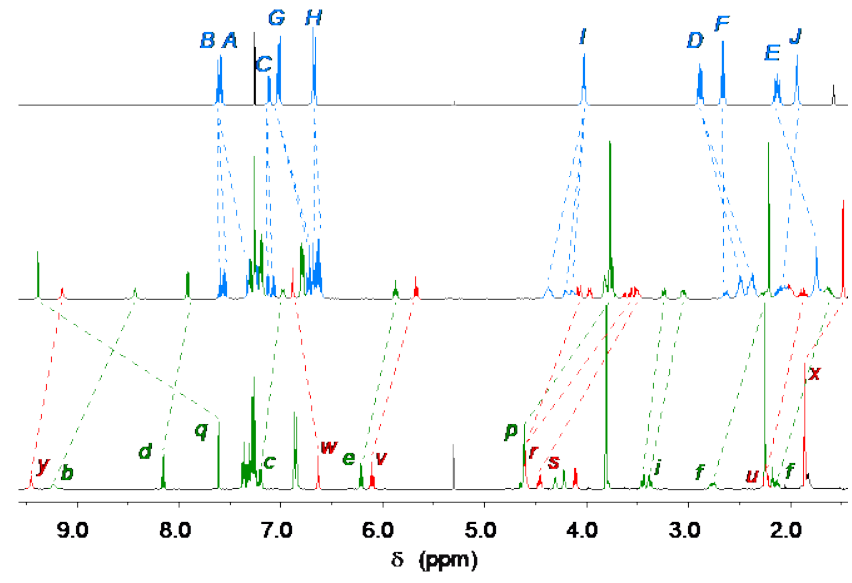

Figure 1. ${ }^{1} \mathrm{H} \mathrm{NMR}\left(400 \mathrm{MHz}, \mathrm{CDCl}_{3}, 298 \mathrm{~K}\right.$ ) with selected signals assigned (see Scheme 1 for atom labels) of a) macrocycle 3 ; b) rotaxane 4 ; c) the corresponding noninterlocked axle.

Scheme 2. a) AT-CuAAC synthesis of $\mathrm{T}_{7}$-rotaxanes $7 \mathbf{a}$ and $\mathbf{7 b}{ }^{a}$ b) Control compounds $\mathrm{T}_{7}$ forward, $\mathrm{T}_{7}$ complementary and axles $\mathbf{9 a}$ and $\mathbf{9 b}$.

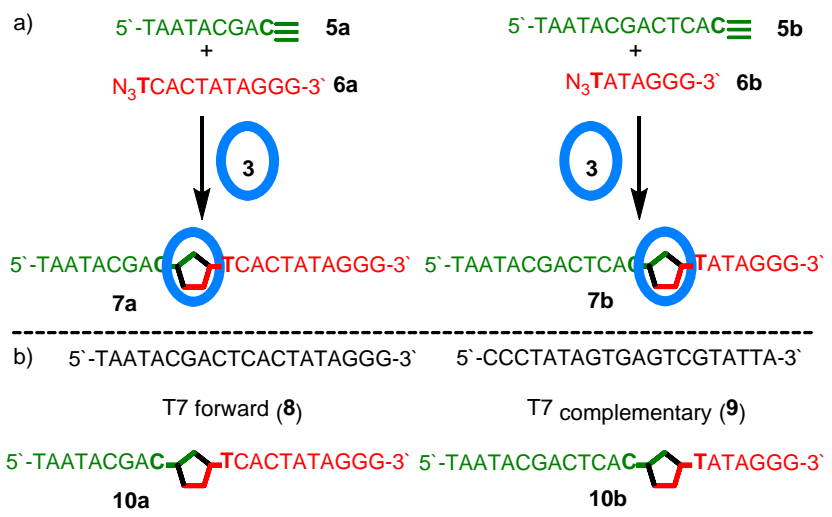

${ }^{a}$ Reagents and conditions: (i) macrocycle 3 (21 equiv.), $\mathrm{CuSO}_{4}$ (10 equiv.), $\mathrm{Na}$ ascorbate (5o equiv.), ${ }^{i} \mathrm{Pr}_{2} \mathrm{EtN}$ (10 equiv.), THF- $\mathrm{H}_{2} \mathrm{O}(1: 1), \mathrm{rt}, 16 \mathrm{~h}$.
To evaluate the effect of the mechanical bond on duplex formation, rotaxanes 7 were annealed with the $\mathrm{T}_{7}$ complementary (9) oligonucleotide and the resulting mixture was analyzed by circular dichroism (CD) spectroscopy. Whereas the native $\mathrm{T}_{7}$ forward (8) and non-interlocked triazolecontaining oligonucleotides 10 displayed the expected CD signals at rt between 180 and $200 \mathrm{~nm}$ associated with expression of helicity in a DNA duplex, ${ }^{19,20}$ rotaxanes 7 display weak $\mathrm{CD}$ signals between $18 \mathrm{o}$ and $200 \mathrm{~nm}$. Furthermore, raising the temperature slowly to "melt" the duplex led to the expected sharp decrease in the $C D$ signal associated with duplex formation in the case of samples derived from $\mathbf{8}$ and 10, whereas no sharp transition associated with duplex disassembly was observed for rotaxanes $7 \cdot{ }^{19}$ Taken together, these results imply that rotaxanes 7 do not hybridize to form a DNA duplex with their complementary strand, and thus DNA hybridization is completely suppressed by the mechanical bond.

Scheme 3. Annealing of rotaxanes $7, \mathrm{~T}_{7}$ forward (8) and axles 10 with $\mathrm{T}_{7}$ complementary (9) and their melting temperature $\left(\mathrm{T}_{\mathrm{m}}\right)$ determined by $\mathrm{CD}$ spectroscopy.

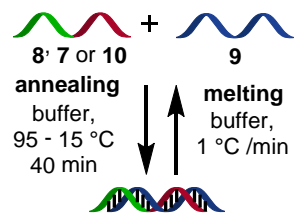

$\begin{array}{ccc}\text { Entry } & \text { Forward strand } & \mathbf{T}_{\mathbf{m}} /{ }^{\circ} \mathbf{C} \\ 1 & \mathbf{8} & 47.0 \\ 2 & \mathbf{7 a} & \text { no duplex } \\ 3 & \mathbf{7 b} & \text { no duplex } \\ 4 & \mathbf{1 0 a} & 38.0 \\ 5 & \mathbf{1 0 b} & 39.5\end{array}$

${ }^{a}$ Annealing conditions: $10 \mu \mathrm{M}$, buffer- $\mathrm{H}_{2} \mathrm{O}$ (8:1), $95-15{ }^{\circ} \mathrm{C}$ over $40 \mathrm{~min}$.

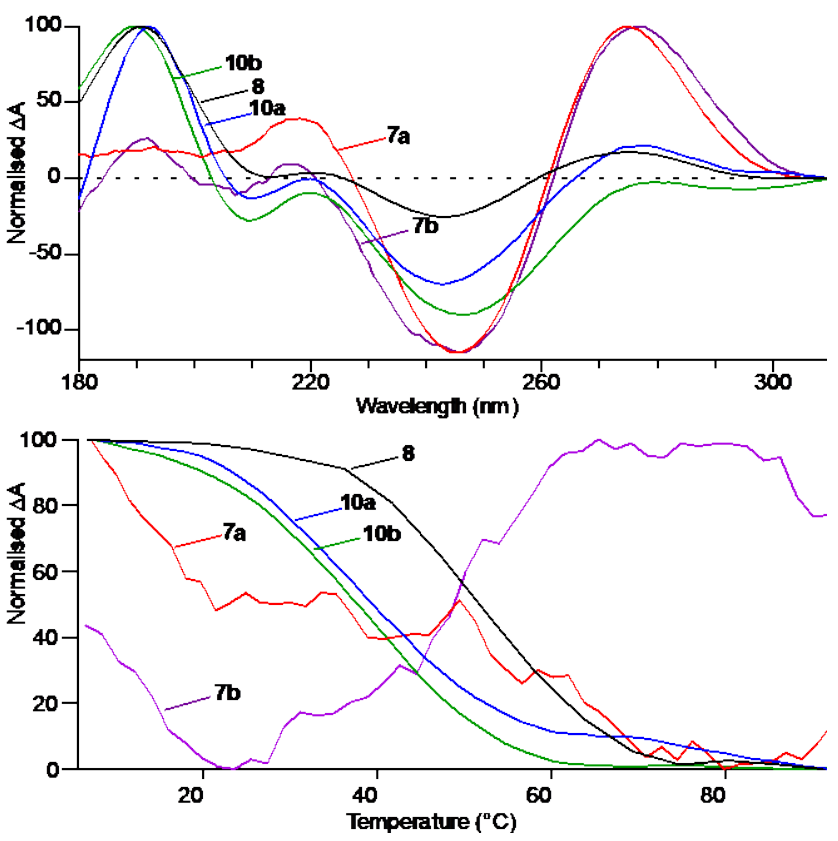

Figure 2. a) normalized CD spectra $\left(25^{\circ} \mathrm{C}\right)$ of axle $7 \mathbf{a}, \mathrm{T}_{7}$ forward (8), rotaxane $10 a$ annealed with $\mathrm{T}_{7}$ complementary (9). b) normalized CD melting curves (190 nm) of 7a, 7b, 8, 10a, 1ob annealed with 9.

The failure of rotaxanes 7 to form a duplex with their complementary strand suggests that the mechanical bond acts to "cage" the oligonucleotide. Caged DNA and RNA based on covalent modification of the native base pairs have been developed to allow selective control of biological function. ${ }^{21}$ Typically, however, multiple points of modification are re- 
quired for efficient suppression of hybridization, ${ }^{22}$ whereas in the case of rotaxanes 7 it appears that a single modification is sufficient to achieve complete suppression of duplex formation.

To demonstrate a potential biological consequence of this result, we examined the behavior of rotaxanes $7 \mathbf{a}$ and $7 \mathbf{b}$ when used as primers for PCR. The native $\mathrm{T}_{7}$ forward primers and non-interlocked triazole-containing oligonucleotides 1oa and 1ob were used as positive controls. Both of these control primers successfully amplified a 1000 bp fragment from a template plasmid at various annealing temperatures $\left(55^{\circ} \mathrm{C}, 41^{\circ} \mathrm{C}\right.$ and $\left.32{ }^{\circ} \mathrm{C}\right)$ to give a single band of the expected molecular weight (Figure 3 ). However, in line with the lack of duplex formation suggested by the melting experiments, when oligonucleotide rotaxanes $\mathbf{7 a}$ and $\mathbf{7} \mathbf{b}$ were used as forward primer for PCR amplification, no amplification was observed even at the relatively low annealing temperature of $32{ }^{\circ} \mathrm{C}$ (Figure 3). Based on these results, the mechanical bond in rotaxanes $\mathbf{7 a}$ and $\mathbf{7} \mathbf{b}$ effectively suppresses the ability of the interlocked oligonucleotide to function as a primer for $\mathrm{T}_{7}$ polymerase.

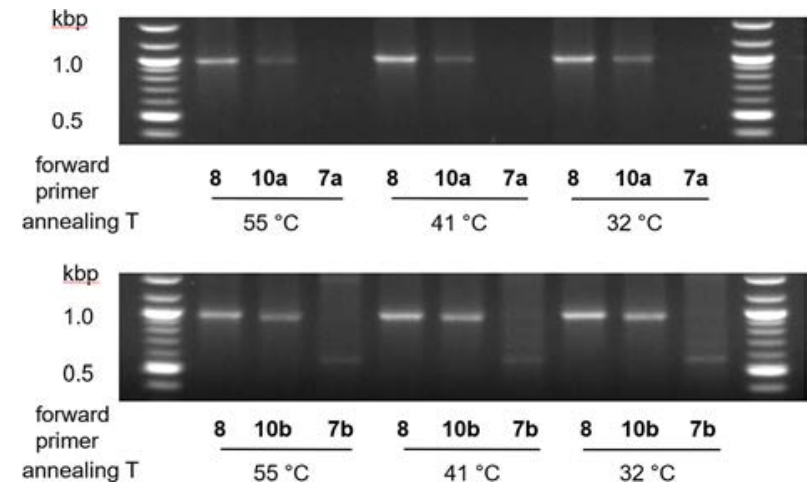

Figure 3. a) Gel analysis of the PCR amplification products of $\mathrm{T}_{7}$ forward (8), rotaxanes 7 and axles 10 at annealing temperatures $55^{\circ} \mathrm{C}, 41^{\circ} \mathrm{C}, 32^{\circ} \mathrm{C}$.

In conclusion, we have demonstrated that the CuAAC approach used in click-DNA ligation can be readily extended to the active template manifold in order to generate rotaxanes based on biocompatible triazole-linked oligonucleotides. Furthermore, whereas the non-interlocked axles are able to form a duplex with their complementary strand and also function as primer sequences for the amplification of an oligonucleotide, the interlocked products are not; duplex formation and PCR amplification are completely suppressed by a single macrocycle encircling the axle, demonstrating that the mechanical bond is an efficient modification for the "caging" of oligonucleotides. Although interlocked molecules are well known as components of artificial molecular machines, ${ }^{23}$ interest in their biological applications has grown in recent years, ${ }^{24}$ including as pro-drugs, ${ }^{25}$ sensors, ${ }^{26}$ and delivery agents for biologically active molecules. ${ }^{27}$ Based on our preliminary results, mechanical bonding has a key role to play in the development of artificial stimuli responsive DNA for real time chemical biology investigation of gene expression and protein function. ${ }^{21}$ Future work will focus on the development of cleavable macrocycles that can be removed in response to external or biological stimuli to reactivate oligonucleotide bioactivity and extending our approach to longer oligonucleotides and plasmids.
Full experimental details and characterization data for all novel compounds. The Supporting Information is available free of charge on the ACS Publications website as a PDF file.

\section{AUTHOR INFORMATION}

\section{Corresponding Author}

*A.Tavassoli@soton.ac.uk

*s.goldup@soton.ac.uk.

\section{Author Contributions}

‡These authors contributed equally.

\section{ACKNOWLEDGMENT}

We thank the University of Southampton, EPSRC (EP/Lo16621/1), BBSRC (BB/Joo1694/2) and ERC (724987) for financial support. M. G. thanks the EPRSC for a Doctoral Prize. A.A.J. is a Marie-Curie Fellow (798304). S.M.G is a Royal Society Wolfson Research Fellow.

\section{REFERENCES}

(1) (a) Evans, N. H.; Beer, P. D. Progress in the Synthesis and Exploitation of Catenanes since the Millennium. Chem. Soc. Rev. 2014, 43, 4658. (b) Xue, M.; Yang, Y.; Chi, X.; Yan, X.; Huang, F. Development of Pseudorotaxanes and Rotaxanes: From Synthesis to Stimuli-Responsive Motions to Applications. Chem. Rev. 2015, 115, 7398. (c) Leigh, D. A.; Gil-Ramírez, G. G.; Leigh, D. A.; Stephens, A. J.; Gil-Ramírez, G. G.; Leigh, D. A.; Stephens, A. J. Catenanes: Fifty Years of Molecular Links. Angew. Chem. Int. Ed. 2015, 54, 6110. (d) Bruns, C. J.; Stoddart, J. F. The Nature of the Mechanical Bond: From Molecules to Machines; Wiley, 2016. (e) Lewis, J. E. M.; Beer, P. D.; Loeb, S. J.; Goldup, S. M. Metal Ions in the Synthesis of Interlocked Molecules and Materials. Chem. Soc. Rev. 2017, 46, 2577.

(2) Threaded peptidic structures also occur naturally. Selected examples of natural and synthetic peptidic interlocked molecules: (a) Rosengren, K. J.; Clark, R. J.; Daly, N. L.; Göransson, U.; Jones, A.; Craik, D. J. Microcin J25 Has a Threaded Sidechain-toBackbone Ring Structure and Not a Head-to-Tail Cyclized Backbone. J. Am. Chem. Soc. 2003, 125, 12464. (b) Bayro, M. J.; Mukhopadhyay, J.; Swapna, G. V. T.; Huang, J. Y.; Ma, L. C.; Sineva, E.; Dawson, P. E.; Montelione, G. T.; Ebright, R. H. Structure of Antibacterial Peptide Microcin J25: A 21-Residue Lariat Protoknot. J. Am. Chem. Soc. 2003, 125, 12382. (c) Wilson, K. A.; Kalkum, M.; Ottesen, J.; Yuzenkova, J.; Chait, B. T.; Landick, R.; Muir, T.; Severinov, K.; Darst, S. A. Structure of Microcin J25, a Peptide Inhibitor of Bacterial RNA Polymerase, Is a Lassoed Tail. J. Am. Chem. Soc. 2003, 125, 12475. (d) Aucagne, V.; Leigh, D. A.; Lock, J. S.; Thomson, A. R. Rotaxanes of Cyclic Peptides. J. Am. Chem. Soc. 20o6, 128, 1784. (e) Hegemann, J. D.; Zimmermann, M.; Zhu, S.; Steuber, H.; Harms, K.; Xie, X.; Marahiel, M. A. XanthomoninsI-III: A New Class of Lasso Peptides with a Seven-Residue Macrolactam Ring. Angew. Chem. Int. Ed. 2014, 53, 2230. (f) Hegemann, J. D.; Zimmermann, M.; Xie, X.; Marahiel, M. A. Lasso Peptides: An Intriguing Class of Bacterial Natural Products. Acc. Chem. Res. 2015, 48, 1909. (g) Bruns, C. J.; Liu, H.; Francis, M. B. Near-Quantitative Aqueous Synthesis of Rotaxanes via Bioconjugation to Oligopeptides and Proteins. J. Am. Chem. Soc. 2016, 138, 15307. (h) Zong, C.; Wu, M. J.; Qin, J. Z.; Link, A. J. Lasso Peptide Benenodin-1 Is a Thermally Actuated [1]Rotaxane Switch. J. Am. Chem. Soc. 2017, 139, 10403. (i) Martin-Gómez, H.; Tulla-Puche, J. Lasso Peptides: Chemical Approaches and Structural Elucidation. Org. Biomol. Chem. 
2018, 16, 5065. (j) Chen, M.; Wang, S.; Yu, X. CryptandImidazolium Supported Total Synthesis of the Lasso Peptide BI32169 and Its D-Enantiomer. Chem. Commun. 2019, 55, 3323.

(3) (a) Wasserman, E. The Preparation of Interlocking Rings: A Catenane. J. Am. Chem. Soc. 196o, 82, 4433. (b) Schill, G.; Lüttringhaus, A. The Preparation of Catena Compounds by Directed Synthesis. Angew. Chem. Int. Ed. 1964, 3, 546. (c) Harrison, I. T.; Harrison, S. Synthesis of a Stable Complex of a Macrocycle and a Threaded Chain. J. Am. Chem. Soc. 1967, 89, 5723.

(4) Witz, G.; Stasiak, A. DNA Supercoiling and Its Role in DNA Decatenation and Unknotting. Nucleic Acids Res. 2010, 38 , 2119.

(5) (a) Clayton, D. A.; Vinograd, J. Circular Dimer and Catenate Forms of Mitochondrial DNA in Human Leukaemic Leucocytes. Nature 1967, 216, 652. (b) Hudson, B.; Vinograd, J. Catenated Circular DNA Molecules in HeLa Cell Mitochondria. Nature 1967, 216, 647.

(6) Makis, H.; Kornberg, A. The Polymerase Subunit of DNA Polymerase III of Escherichia Coli. J. Biol. Chem. 1985, 26o, 12987. (b) Stukenberg, P. T.; Studwell-Vaughan, P. S.; O’Donnell, M. Mechanism of the Sliding Beta-Clamp of DNA Polymerase III Holoenzyme. J. Biol. Chem. 1991, 266, 11328.

(7) Selected examples of molecular machines inspired by interlocked enzymes: (a) Thordarson, P.; Bijsterveld, E. J. A.; Rowan, A. E.; Nolte, R. J. M. Epoxidation of Polybutadiene by a Topologically Linked Catalyst. Nature 2003, 424, 915. (b) Lewandowski, B.; De Bo, G.; Ward, J. W.; Papmeyer, M.; Kuschel, S.; Aldegunde, M. J.; Gramlich, P. M. E.; Heckmann, D.; Goldup, S. M.; D’Souza, D. M.; Fernandes, A. E.; Leigh, D. A. SequenceSpecific Peptide Synthesis by an Artificial Small-Molecule Machine. Science 2013, 339, 189. (c) van Dongen, S. F. M.; Clerx, J.; Nørgaard, K.; Bloemberg, T. G.; Cornelissen, J. J. L. M.; Trakselis, M. A.; Nelson, S. W.; Benkovic, S. J.; Rowan, A. E.; Nolte, R. J. M. A Clamp-like Biohybrid Catalyst for DNA Oxidation. Nat. Chem. 2013, 5, 945. (d) De Bo, G.; Gall, M. A. Y. Y.; Kuschel, S.; De Winter, J.; Gerbaux, P.; Leigh, D. A. An Artificial Molecular Machine That Builds an Asymmetric Catalyst. Nat. Nanotechnol. 2018, 13, 381.

(8) (a) Ryan, K.; Kool, E. T. Triplex-Directed Self-Assembly of an Artificial Sliding Clamp on Duplex DNA. Chem. Biol. 1998, 5, 59. (b) Kuhn, H.; Demidov, V. V.; Frank-Kamenetskii, M. D. An Earring for the Double Helix: Assembly of Topological Links Comprising Duplex DNA and a Circular Oligodeoxynucleotide. J. Biomol. Struct. Dyn. 20oo, 17, 221. (c) Weizmann, Y.; Braunschweig, A. B.; Wilner, O. I.; Cheglakov, Z.; Willner, I. A Polycatenated DNA Scaffold for the One-Step Assembly of Hierarchical Nanostructures. Proc. Natl. Acad. Sci. 2008, 105, 5289. (d) Ackermann, D.; Schmidt, T. L.; Hannam, J. S.; Purohit, C. S.; Heckel, A.; Famulok, M. A Double-Stranded DNA Rotaxane. Nat. Nanotechnol. 2o10, 5, 436. (e) Schmidt, T. L.; Heckel, A. Construction of a Structurally Defined DoubleStranded DNA Catenane. Nano Lett. 2011, 11, 1739. (f) Cecconello, A.; Lu, C.-H.; Elbaz, J.; Willner, I. Au Nanoparticle/DNA Rotaxane Hybrid Nanostructures Exhibiting Switchable Fluorescence Properties. Nano Lett. 2o13, 13, 6275. (g) Liu, M.; Zhang, Q.; Li, Z.; Gu, J.; Brennan, J. D.; Li, Y. Programming a Topologically Constrained DNA Nanostructure into a Sensor. Nat. Commun. 2016, 7, 12074. (h) Valero, J.; Lohmann, F.; Famulok, M. Interlocked DNA Topologies for Nanotechnology. Curr. Opin. Biotechnol. 2017, 48, 159. (i) Centola, M.; Valero, J.; Famulok, M. Allosteric Control of Oxidative Catalysis by a DNA Rotaxane Nanostructure. J. Am. Chem. Soc. 2017, 139, 16044.

(9) Selected reviews: (a) Rothemund, P. W. K. Folding DNA to Create Nanoscale Shapes and Patterns. Nature 2oo6, 440, 297. (b) Bath, J.; Turberfield, A. J. DNA Nanomachines. Nat.
Nanotechnol. 2007, 2, 275. (c) Castro, C. E.; Kilchherr, F.; Kim, D.-N.; Shiao, E. L.; Wauer, T.; Wortmann, P.; Bathe, M.; Dietz, H. A Primer to Scaffolded DNA Origami. Nat. Methods 2o11, 8, 221. (c) Stulz, E. DNA Architectonics: Towards the Next Generation of Bio-Inspired Materials. Chem. - A Eur. J. 2012, 18, 4456. (d) Tørring, T.; Voigt, N. V.; Nangreave, J.; Yan, H.; Gothelf, K. V. DNA Origami: A Quantum Leap for Self-Assembly of Complex Structures. Chem. Soc. Rev. 2011, 40, 5636. (e) Seeman, N. C. Structural DNA Nanotechnology; Cambridge University Press: Cambridge, 2015. (f) Hong, F.; Zhang, F.; Liu, Y.; Yan, H. DNA Origami: Scaffolds for Creating Higher Order Structures. Chem. Rev. 2017, 117, 12584. (g) Bujold, K. E.; Lacroix, A.; Sleiman, H. F. DNA Nanostructures at the Interface with Biology. Chem 2018, 4, 495.

(10) (a) El-Sagheer, A. H.; Brown, T. Synthesis and Polymerase Chain Reaction Amplification of DNA Strands Containing an Unnatural Triazole Linkage. J. Am. Chem. Soc. 2009, 131, 3958. (b) El-Sagheer, A. H.; Sanzone, A. P.; Gao, R.; Tavassoli, A.; Brown, T. Biocompatible Artificial DNA Linker That Is Read through by DNA Polymerases and Is Functional in Escherichia Coli. Proc. Natl. Acad. Sci. 2011, 108, 11338. (c) El-Sagheer, A. H.; Brown, T. A Triazole Linkage That Mimics the DNA Phosphodiester Group in Living Systems. Q. Rev. Biophys. 2015, $48,429$.

(11) Kukwikila, M.; Gale, N.; El-Sagheer, A. H.; Brown, T.; Tavassoli, A. Assembly of a Biocompatible Triazole-Linked Gene by One-Pot Click-DNA Ligation. Nat. Chem. 2017, 9, 1089.

(12) (a) Crowley, J. D.; Goldup, S. M.; Lee, A.-L.; Leigh, D. A.; McBurney, R. T. Active Metal Template Synthesis of Rotaxanes, Catenanes and Molecular Shuttles. Chem. Soc. Rev. 2oo9, 38, 1530. (b) Saito, S. Synthesis of Interlocked Compounds Utilizing the Catalytic Activity of Macrocyclic Phenanthroline-Cu Complexes. J. Incl. Phenom. Macrocycl. Chem. 2015, 82, 437. (c) Denis, M.; Goldup, S. M. The Active Template Approach to Interlocked Molecules. Nat. Rev. Chem. 2017, 1, oo61.

(13) (a) Tornøe, C. W.; Christensen, C.; Meldal, M. Peptidotriazoles on Solid Phase: $[1,2,3]$-Triazoles by Regiospecific Copper(i)-Catalyzed 1,3-Dipolar Cycloadditions of Terminal Alkynes to Azides. J. Org. Chem. 2oo2, 67, 3057. (b) Rostovtsev, V. V; Green, L. G.; Fokin, V. V; Sharpless, K. B. A Stepwise Huisgen Cycloaddition Process: Copper(I)-Catalyzed Regioselective "Ligation" of Azides and Terminal Alkynes. Angew. Chem. Int. Ed. 2002, 41, 2596.

(14) (a) Aucagne, V.; Hänni, K. D.; Leigh, D. A.; Lusby, P. J.; Walker, D. B. Catalytic "Click" Rotaxanes: A Substoichiometric Metal-Template Pathway to Mechanically Interlocked Architectures. J. Am. Chem. Soc. 20o6, 128, 2186. (b) Aucagne, V.; Berna, J.; Crowley, J. D.; Goldup, S. M.; Hänni, K. D.; Leigh, D. A.; Lusby, P. J.; Ronaldson, V. E.; Slawin, A. M. Z.; Viterisi, A.; Walker, D. B. Catalytic "Active-Metal" Template Synthesis of [2]Rotaxanes, [3]Rotaxanes, and Molecular Shuttles, and Some Observations on the Mechanism of the $\mathrm{Cu}(\mathrm{i})$-Catalyzed AzideAlkyne 1,3-Cycloaddition. J. Am. Chem. Soc. 2007, 129, 11950.

(15) (a) Lahlali, H.; Jobe, K.; Watkinson, M.; Goldup, S. M. Macrocycle Size Matters: "Small" Functionalized Rotaxanes in Excellent Yield Using the CuAAC Active Template Approach. Angew. Chem. Int. Ed. 2011, 50, 4151. (b) Neal, E. A.; Goldup, S. M. Competitive Formation of Homocircuit [3]Rotaxanes in Synthetically Useful Yields in the Bipyridine-Mediated Active Template CuAAC Reaction. Chem. Sci. 2015, 6, 2398. (c) Lewis, J. E. M.; Winn, J.; Cera, L.; Goldup, S. M. Iterative Synthesis of Oligo[ n ]Rotaxanes in Excellent Yield. J. Am. Chem. Soc. 2016, 138, 16329. (d) Lewis, J. E. M.; Modicom, F.; Goldup, S. M. Efficient Multicomponent Active Template Synthesis of Catenanes. J. Am. Chem. Soc. 2018, 140, 4787.

(16) Lewis, J. E. M.; Bordoli, R. J.; Denis, M.; Fletcher, C. J.; 
Galli, M.; Neal, E. A.; Rochette, E. M.; Goldup, S. M. High Yielding Synthesis of 2,2'-Bipyridine Macrocycles, Versatile Intermediates in the Synthesis of Rotaxanes. Chem. Sci. 2016, 7, 3154.

(17) Jamieson, E. M. G.; Modicom, F.; Goldup, S. M. Chirality in Rotaxanes and Catenanes. Chem. Soc. Rev. 2018, 47, 5266.

(18) Rong, M.; He, B.; McAllister, W. T.; Durbin, R. K. Promoter Specificity Determinants of $\mathrm{T}_{7}$ RNA Polymerase. Proc. Natl. Acad. Sci. 1998, 95, 515.

(19) Kypr, J.; Kejnovská, I.; Renčiuk, D.; Vorlíčková, M. Circular Dichroism and Conformational Polymorphism of DNA. Nucleic Acids Res. 2009, 37, 1713.

(20) A reduced $\mathrm{T}_{\mathrm{m}}\left(\Delta \mathrm{T}_{\mathrm{m}}=7-14{ }^{\circ} \mathrm{C}\right)$ is expected for click-DNA oligonucleotides: Dallmann, A.; El-Sagheer, A. H.; Dehmel, L.; Mügge, C.; Griesinger, C.; Ernsting, N. P.; Brown, T. Structure and Dynamics of Triazole-Linked DNA: Biocompatibility Explained. Chem. - A Eur. J. 2011, 17, 14714.

(21) Selected reviews: (a) Casey, J. P.; Blidner, R. A.; Monroe, W. T. Caged SiRNAs for Spatiotemporal Control of Gene Silencing. Mol. Pharm. 2oo9, 6, 669. (b) Matsushita-Ishiodori, Y.; Ohtsuki, T. Photoinduced RNA Interference. Acc. Chem. Res. 2012, 45, 1039. (c) Ceo, L. M.; Koh, J. T. Photocaged DNA Provides New Levels of Transcription Control. ChemBioChem 2012, 13, 511. (d) Tang, X.; Zhang, J.; Sun, J.; Wang, Y.; Wu, J.; Zhang, L. Caged Nucleotides/Nucleosides and Their Photochemical Biology. Org. Biomol. Chem. 2013, 11, 7814. (e) Liu, Q.; Deiters, A. Optochemical Control of Deoxyoligonucleotide Function via a Nucleobase-Caging Approach. Acc. Chem. Res. 2014, 47, 45. (f) Lubbe, A. S.; Szymanski, W.; Feringa, B. L. Recent Developments in Reversible Photoregulation of Oligonucleotide Structure and Function. Chem. Soc. Rev. 2017, 46, 1052. (g) Debart, F.; Dupouy, C.; Vasseur, J. J. StimuliResponsive Oligonucleotides in Prodrug-Based Approaches for Gene Silencing. Beilstein J. Org. Chem. 2018, 14, 436. (h) Ankenbruck, N.; Courtney, T.; Naro, Y.; Deiters, A Optochemical Control of Biological Processes in Cells and Animals. Angew. Chem. Int. Ed. 2018, 57, 2768.

(22) (a) Yamaguchi, S.; Chen, Y.; Nakajima, S.; Furuta, T.; Nagamune, T. Light-Activated Gene Expression from SiteSpecific Caged DNA with a Biotinylated Photolabile Protection Group. Chem. Commun. 2010, 46, 2244. (b) Prokup, A.; Hemphill, J.; Deiters, A. DNA Computation: A Photochemically Controlled and Gate. J. Am. Chem. Soc. 2012, 134, 3810.

(23) (a) Coskun, A.; Banaszak, M.; Astumian, R. D.; Stoddart, J. F.; Grzybowski, B. A. Great Expectations: Can Artificial Molecular Machines Deliver on Their Promise? Chem. Soc. Rev. 2012, 41, 19. (b) Erbas-Cakmak, S.; Leigh, D. A.; McTernan, C. T.; Nussbaumer, A. L. Artificial Molecular Machines. Chem. Rev. 2015, 115, 10081. (c) Feringa, B. L. The Art of Building Small: From Molecular Switches to Motors (Nobel Lecture). Angew. Chem. Int. Ed. 2017, 56, 1106o. (d) Sauvage, J. P. From Chemical Topology to Molecular Machines (Nobel Lecture). Angew. Chem. Int. Ed. 2017, 56, 1108o. (e) Stoddart, J. F. Mechanically Interlocked Molecules (MIMs)-Molecular Shuttles, Switches, and Machines (Nobel Lecture). Angew. Chem. Int. Ed. 2017, 56, 11094

(24) (a) Higashi, T.; Motoyama, K.; Arima, H. CyclodextrinBased Polyrotaxanes and Polypseudorotaxanes as Drug Delivery Carriers. J. Drug Deliv. Sci. Technol. 2013, 23, 523. (b) OrnelasMegiatto, C.; Becher, T.; Megiatto, J. Interlocked Systems in Nanomedicine. Curr. Top. Med. Chem. 2015, 15, 1236. (c) Ma, X.; Zhao, Y. Biomedical Applications of Supramolecular Systems Based on Host-Guest Interactions. Chem. Rev. 2015, 115, 7794. (d) Pairault, N.; Barat, R.; Tranoy-Opalinski, I.; Renoux, B.; Thomas, M.; Papot, S. Rotaxane-Based Architectures for Biological Applications. Comptes Rendus Chim. 2016, 19, 103. (e) Webber,
M. J.; Langer, R. Drug Delivery by Supramolecular Design. Chem. Soc. Rev. 2017, 46, 660o. (f) Yu, G.; Yung, B. C.; Zhou, Z.; Mao, Z.; Chen, X. Artificial Molecular Machines in Nanotheranostics. ACS Nano 2018, $12,7$.

(25) (a) Fernandes, A.; Viterisi, A.; Coutrot, F.; Potok, S.; Leigh, D. A.; Aucagne, V.; Papot, S. Rotaxane-Based Propeptides: Protection and Enzymatic Release of a Bioactive Pentapeptide. Angew. Chem. Int. Ed. 2009, 48, 6443. (b) Fernandes, A.; Viterisi, A.; Aucagne, V.; Leigh, D. A.; Papot, S. Second Generation Specific-Enzyme-Activated Rotaxane Propeptides. Chem. Commun. 2012, 48, 2083. (c) Barat, R.; Legigan, T.; TranoyOpalinski, I.; Renoux, B.; Péraudeau, E.; Clarhaut, J.; Poinot, P.; Fernandes, A. E.; Aucagne, V.; Leigh, D. A.; Papot, S. A Mechanically Interlocked Molecular System Programmed for the Delivery of an Anticancer Drug. Chem. Sci. 2015, 6, 2608. (d) Sojka, M.; Fojtu, M.; Fialova, J.; Masarik, M.; Necas, M.; Marek, R. Locked and Loaded: Ruthenium(II)-Capped Cucurbit[n]UrilBased Rotaxanes with Antimetastatic Properties. Inorg. Chem. 2019, 58, 10861.

(26) (a) Baumes, J. M.; Gassensmith, J. J.; Giblin, J.; Lee, J.-J.; White, A. G.; Culligan, W. J.; Leevy, W. M.; Kuno, M.; Smith, B. D. Storable, Thermally Activated, near-Infrared Chemiluminescent Dyes and Dye-Stained Microparticles for Optical Imaging. Nat Chem 2010, 2, 1025. (b) Langton, M. J.; Robinson, S. W.; Marques, I.; Félix, V.; Beer, P. D. Halogen Bonding in Water Results in Enhanced Anion Recognition in Acyclic and Rotaxane Hosts. Nat. Chem. 2014, 6, 1039. (c) Mitra, R.; Thiele, M.; Octa-Smolin, F.; Letzel, M. C.; Niemeyer, J. A Bifunctional Chiral [2]Catenane Based on 1,1'-BinaphthylPhosphates. Chem. Commun. 2016, 52, 5977. (d) Denis, M.; Pancholi, J.; Jobe, K.; Watkinson, M.; Goldup, S. M. Chelating Rotaxane Ligands as Fluorescent Sensors for Metal Ions. Angew. Chem. Int. Ed. 2018, 57, 5310. (e) Denis, M.; Qin, L.; Turner, P.; Jolliffe, K. A.; Goldup, S. M. A Fluorescent Ditopic Rotaxane IonPair Host. Angew. Chem. Int. Ed. 2018. (f) Lim, J. Y. C. C.; Marques, I.; Félix, V.; Beer, P. D. A Chiral Halogen-Bonding [3]Rotaxane for the Recognition and Sensing of Biologically Relevant Dicarboxylate Anions. Angew. Chem. Int. Ed. 2018, 57, 584 .

(27) (a) Smukste, I.; House, B. E.; Smithrud, D. B. Host[2]Rotaxane: Advantage of Converging Functional Groups for Guest Recognition. J. Org. Chem. 2003, 68, 2559. (b) Ooya, T.; Choi, H. S.; Yamashita, A.; Yui, N.; Sugaya, Y.; Kano, A.; Maruyama, A.; Akita, H.; Ito, R.; Kogure, K.; Harashima, H. Biocleavable Polyrotaxane - Plasmid DNA Polyplex for Enhanced Gene Delivery. J. Am. Chem. Soc. 2006, 128, 3852. (c)Bao, X.; Isaacsohn, I.; Drew, A. F.; Smithrud, D. B. Determining the Binding and Intracellular Transporting Abilities of a Host[3]Rotaxane. J. Org. Chem. 2007, 72, 3988. (d) Wang, X.; Bao, X.; McFarland-Mancini, M.; Isaacsohn, I.; Drew, A. F.; Smithrud, D. B. Investigation of the Intracellular Delivery of Fluoresceinated Peptides by a Host-[2]Rotaxane. J. Am. Chem. Soc. 2007, 129, 7284. (e) Patel, K.; Angelos, S.; Dichtel, W. R.; Coskun, A.; Yang, Y. W.; Zink, J. I.; Stoddart, J. F. Enzyme-Responsive Snap-Top Covered Silica Nanocontainers. J. Am. Chem. Soc. 20o8, 130, 2382. (f) Cotí, K. K.; Belowich, M. E.; Liong, M.; Ambrogio, M. W.; Lau, Y. A.; Khatib, H. A.; Zink, J. I.; Khashab, N. M.; Stoddart, J. F. Mechanised Nanoparticles for Drug Delivery. Nanoscale 2009, 1, 16. (g) Kulkarni, A.; Defrees, K.; Schuldt, R. A.; Hyun, S. H.; Wright, K. J.; Yerneni, C. K.; Verheul, R.; Thompson, D. H. Cationic $\alpha$-Cyclodextrin:Poly(Ethylene Glycol) Polyrotaxanes for SiRNA Delivery. Mol. Pharm. 2013, 10, 1299. (h) Ardeleanu, R.; Dascalu, A. I.; Neamtu, A.; Peptanariu, D.; Uritu, C. M.; Maier, S. S.; Nicolescu, A.; Simionescu, B. C.; Barboiu, M.; Pinteala, M. Multivalent Polyrotaxane Vectors as Adaptive Cargo Complexes for Gene Therapy. Polym. Chem. 2018, 9, 845. 
TOC graphic

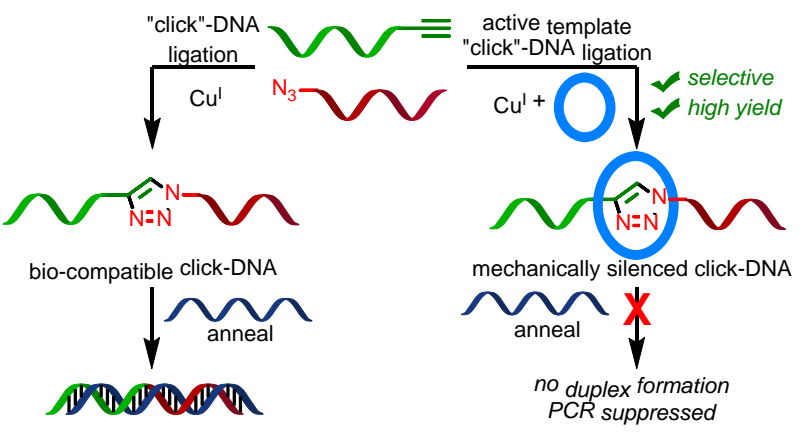

